\section{APSA Awards}

$\mathrm{R}$ ecognizing excellence in the profession is one of the most important roles of APSA. Through the service of member committees who review nominations, APSA confers awards for the best dissertations, papers and articles, and books in the various subfields of the discipline as well as for career achievement in research, teaching, and service to the discipline. The 2019 APSA Awards were presented at the annual meeting on Wednesday, August 28.

\section{FRANK J. GOODNOW AWARD}

The Frank Johnson Goodnow Award was established by the APSA Council in 1996 to honor service to the community of teachers, researchers, and public servants who work in the many fields of politics. Frank J. Goodnow, the first president of the American Political Science Association, a pioneer in the development of judicial politics, and former president of Johns Hopkins University, is an exemplar of the public service and volunteerism that this award represents.

Award Committee: Lynda Powell, Chair, University of Rochester; Sidney Milkis, University of Virginia; Clarence Stone, George Washington University.

\section{Recipient: Jan Leighley, American University}

Citation: Jan Leighley has compiled a remarkable record of public service to our profession. For half of the last 20 years, she edited two of our most prestigious journals. She served as editor of the American Journal of Political Science from 2002 to 2005, editor of the Journal of Politics from 2009 to 2014, and as interim lead editor from 2018 to 2019. These positions involve enormous time commitments and impose substantial personal burdens. Being chosen as such an editor more than once is also recognition of a job done exceptionally well. Her recent service to the AJPS is particularly notable, as during a serious crisis for the journal and the discipline, she and her team worked quickly to get operations back up and running in just one month's time.

Leighley also has served in many capacities in regional and national professional associations. She has been president of two

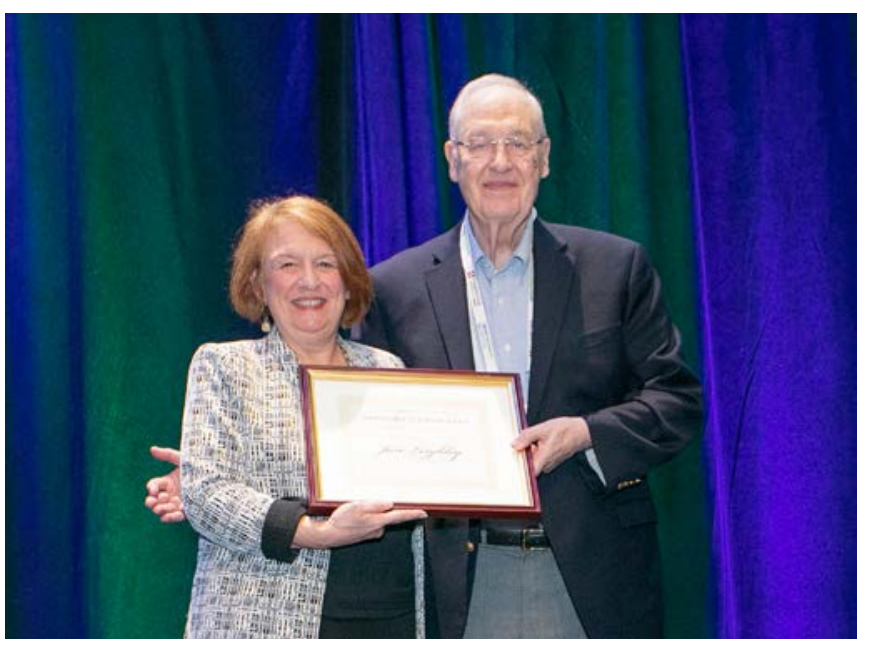

Jan Leighley (left) is presented the Frank J. Goodnow Award by award committee member Clarence Stone (right). professional associations (the Southwestern Political Science Association and the Midwest Political Science Association) and also served as program chair for the annual meetings of both of those associations. Furthermore, she has been the division organizer for two different sections of the American Political Science Association (Elections, Public Opinion, and Voting Behavior; State Politics and Policy), and has served on the councils for both of those sections, as well as innumerable section committees.

Leighley's lengthy and varied list of professional service extends over 25 years. Besides her remarkable service as a journal editor and leading presence in two important disciplinary sections, many scholars have attested to her strong teaching and inspirational mentorship of young scholars. For example, Leighley has given at least a dozen conference panel presentations aimed at helping younger scholars learn such things as how to submit a journal article, get tenure, publish a book, and network professionally.

Leighley's devotion to service might have affected her scholarship; however, like many effective academic leaders she also has been an intellectual leader in political science, writing several influential books published by top university presses and over two dozen peerreviewed articles placed in top-tier journals. Her research focuses on the relationship between class, ethnicity, and income inequality on turnout. Leighley's most recent book, Who Votes Now? (Princeton University Press, 2014), was an important in-depth examination of how resource biases influence turnout and its implications for American politics and society.

In sum, Jan Leighley exemplifies the qualities of intellectual leadership, generous public service and inspiring mentoring that the Goodnow Award honors.

\section{BARBARA SINCLAIR AWARD}

This award commemorates the life and scholarship of renowned scholar of legislative politics Barbara Sinclair. Each year a speaker will be selected to deliver the lecture, held at American University. The inaugural Barbara Sinclair Lecture took place in fall 2018. Speaker selection recognizes achievement in promoting understanding of the US Congress and legislative politics. The lecture and speaker honorarium are cosponsored by the Center for Congressional and Presidential Studies, School of Public Affairs, American University.

Award Committee: David Barker, Co-chair, American University; Janna Deitz, Co-chair, American Political Science Association; Menna Demessie, Congressional Black Caucus Foundation; Molly Reynolds, The Brookings Institution; Sean Theriault, University of Texas, Austin.

\section{Recipient: Frances Lee, University of Maryland}

Citation: Professor Frances Lee will present the 2019 Barbara Sinclair Lecture to the incoming class of American Political Science Association Congressional Fellows, as well as alumni and friends of the Congressional Fellowship Program, this fall.

Professor Lee is professor of politics and public affairs in the Department of Politics at Princeton University, with a joint appointment to the Woodrow Wilson School. Previously, she served on the faculty at the University of Maryland, College Park, from 2004 to 2019. Elected to the American Academy of Arts and Sciences in 
2019, Professor Lee is an eminent scholar of all things Congress, recognized for her extensive academic and popular contributions to the understanding of the legislative branch. Her body of research has been consistently published in the discipline's top journals. Her books have received awards that are among the most prestigious honors for research in legislative politics: namely, the D.B. Hardeman Prize for Sizing Up the Senate: The Unequal Consequences of Equal Representation (coauthored with Bruce Oppenheimer), and the Richard F. Fenno, Jr. Award and D.B. Hardeman Prize for Beyond Ideology: Politics, Principles, and Partisanship. She served as coeditor of Legislative Politics Quarterly and coauthored the widely-adopted textbook Congress and Its Members. Professor Lee's significant contributions to the scholarly study and understanding of Congress are exceptional.

In naming her the presenter of the Barbara Sinclair lecture, the selection committee noted Professor Lee's engaged approach to scholarship and commitment to deepening the public's understanding of Congress. In addition to her impressive record of scholarly achievement, these qualities make her a scholar very much in the tradition of Dr. Barbara Sinclair. Professor Lee's interviews with members of Congress and their staff make her research substantively connected to the nuanced and real-world politics on Capitol Hill. Early in her career, after receiving her $\mathrm{PhD}$ from Vanderbilt, Professor Lee's dissertation received the E.E. Schattschneider Award for best dissertation in American politics by the APSA in 1997. From 2002 to 2003 she served as an APSA Congressional Fellow on the staff of the Senate Democratic Policy Committee and in the office of Congressman Jim Cooper (D-TN). As her nominator noted, "Frances would serve as an example of what the fellowship program aims to create with its alumni: engaged and deeply knowledgeable scholars who translate their time spent on Capitol Hill into insight that moves our understanding of Congress forward and builds long-lasting connections between the world of Congress and the world of political science." For these reasons, we are delighted to name professor Frances Lee the presenter of the 2019 Barbara Sinclair Lecture. Commemorating the scholarship of renowned scholar of legislative politics, Barbara Sinclair, this lecture will take place in fall 2019 at American University and is cosponsored by the Center for Congressional and Presidential Studies, School of Public Affairs at American University and APSA's Congressional Fellowship Program.

\section{Career Awards}

\section{CQ PRESS AWARD FOR TEACHING INNOVATION}

The CQ Press Award for Teaching Innovation is awarded annually to honor a wide range of new directions in teaching. The only limits on what will be recognized are the imagination and creativity of those teaching political science.

Award Committee: Elizabeth Bennett, Chair, Lewis \& Clark College; Warigia Bowman, University of Tulsa; Andrew Teas, Houston Community College.

Recipient: Nicole Kalaf-Hughes, Bowling Green State University Citation: We are delighted to present the 2019 APSA/CQ Press Award for Teaching Recognition to Nicole Kalaf-Hughes, assistant professor of political science at Bowling Green State University. While it would be impossible to convey the breadth and depth of KalafHughes's contributions to teaching, or the enthusiasm expressed by her nomination letter writers, in a short summary, we wish to share with the broader community highlights from her teaching innovations, research on pedagogy, mentorship, and service.

Kalaf-Hughes has taught undergraduate courses on American politics, the presidency, Latino politics, racial and ethnic politics, research methods, state and local politics, legislative-executive relations, and California politics, as well as graduate seminars in American politics, research methods, and racial and ethnic politics. Her nominators describe her teaching as passionate, innovative, challenging, and highly successful in piquing interest and building skills.

Kalaf-Hughes has invested heavily in developing her teaching skills by participating in several pedagogic workshops. She also shares her talent by serving as a leader in the information literacy community at Bowling Green. Most notably, however, is her development of an innovative simulation and her use of data from that simulation to contribute to understanding on how faculty of political science may better engage students through open educational resources.

Over the past four years, Kalaf-Hughes, in collaboration with a colleague, has developed an innovative, co-taught simulation to help students to understand the interplay between national and local issues in Congress, and the relationships between members of congress and executive branch officials. By examining two policy issues-immigration and transportation financing-in a twocourse, co-taught module, the pedagogic model aims to improve upon the shortcomings of single-case simulations and traditional lectures, more effectively building knowledge, skills, and interest in American politics.

To improve the simulation and better understand its role in student engagement, Kalaf-Hughes and her colleague analyzed student responses to anonymous surveys about their experience. Their insights are described in the pedagogic article "Working Together: An Empirical Analysis of a Multiclass Legislative-Executive Branch Simulation," published in the Journal of Political Science Education. Their research adds to a body of knowledge that aims to understand when and how simulations and other open educational resources may improve engagement with material, which has important implications for student engagement and retention. Following up on these findings, Kalaf-Hughes conducted further research on this pedagogic topic. In 2018, she presented her research at the APSA Centennial Center Workshop on Teaching American Government and more recently she was invited to revise and resubmit an article focused on reaching students with low interest in American government courses.

Finally, in addition to these teaching innovations and pedagogic research activities, Kalaf-Hughes has contributed to her students' academic experience by launching the Undergraduate Political Science Association, advising the Pi Sigma Alpha National Political Science Honor Society, and serving on thesis advising, scholarship, and dissertation award committees.

Kalaf-Hughes is clearly "an extremely talented and dedicated teacher" and it is unsurprising that in 2016 she won the Pi Sigma Alpha Teaching Award. We are excited to add to her accolades the 2019 APSA CQ Press Award for Teaching Recognition.

\section{DISTINGUISHED TEACHING AWARD}

The APSA Distinguished Teaching Award honors the outstanding contribution to undergraduate and graduate teaching of political science at two- and four-year institutions. The contribution may span several years or an entire career, or it may be a single project of exceptional impact. 
Award Committee: Maureen Feeley, Chair, University of California, San Diego; Laura Henry, Bowdoin College; H.W. Perry, University of Texas, Austin.

\section{Recipient: Arthur Svenson, University of Redlands}

Citation: We are truly delighted to present the 2019 APSA Distinguished Teaching Award to Professor Arthur Svenson, professor of Constitutional Law at the University of Redlands for the past 37 years, David Boies Endowed Chair since 2004, and recipient of numerous research, service, and outstanding teaching awards over his long and distinguished career. Nearly 60 current and former students wrote letters in enthusiastic support of Professor Svenson's nomination, some of whom were his students more than 30 years ago. These letters speak to Professor Svenson's extraordinary level of dedication as a teacher and mentor, and to the transformative impact his teaching has had not only on his students' professional trajectories, but also on each of them personally. His courses are consistently described as "lifechanging," "inspirational," and "transformational." As one student explains: "Dr. Svenson... genuinely believes [in], pushes, and encourages each student... to think critically, engage in difficult conversations, and approach political science with an interdisciplinary lens. Because Dr. Svenson genuinely believes in each of his student's capacity to be great, they are. He has provided hundreds of students ... with the analytical skills and knowledge to think deeply about how law and policy shape the world in which we live... [He] has continuously gone above and beyond what is required of him to ensure that his students are not only critically engaged with the material, but [also] asking questions that nobody else is asking. I have never felt more inspired, intellectually stimulated, encouraged, and challenged by a professor."

In addition to this overwhelming support by current and former students, Professor Svenson was also enthusiastically endorsed by the chair of his department, his fellow faculty members, his dean, his provost, and the president of the University of Redlands. As his colleagues document: "To read through Art's teaching evaluations is nothing short of humbling. For as many years back as they are preserved in our dean's office, Art's scores in every single category are virtually perfect. .. His pure devotion to his craft is inimitable." Also included in his nominating file were 45 pages of student evaluations, which provide overwhelming evidence of his outstanding contributions to teaching and student mentoring. As the president

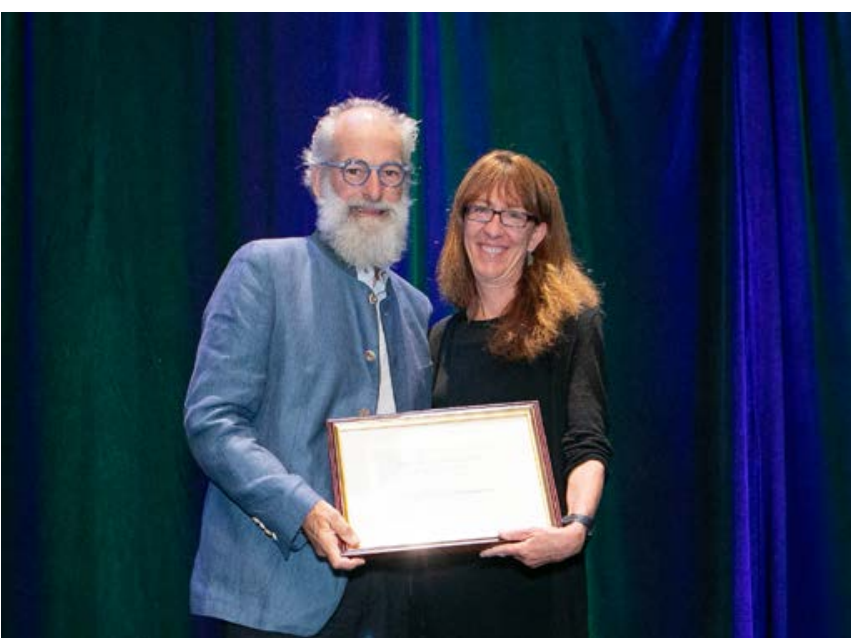

Arthur Svenson (left) receives the APSA Distinguished Teaching Award from award committee chair Maureen C. Feeley (right). of the University of Redlands comments: "Simply put, [Art Svenson] is a legend... Art does more than teach his students. He helps them become the people of character they are destined to be. And they never forget him. How many of us can say we made the greatest difference in the development and life of another human being? Art has done that more than a thousand-fold in his 3o-plus career at Redlands... When alumni return to my campus, there is one person they want to see. And it's Art."

On behalf of the American Political Science Association, the 2019 Distinguished Teaching Award committee would like to congratulate and thank Professor Svenson for nearly four decades of extradorinary dedication and service to his students and to our discipline. His example of excellence in teaching and student mentoring is both inspiring and humbling. It was an honor to read through his numerous achievements in undergraduate education over his long and impactful career. We are honored and delighted to award Professor Svenson APSA's 2019 Distinguished Teaching Award.

\section{JOHN GAUS AWARD}

The John Gaus Award and Lectureship honors the recipient's lifetime of exemplary scholarship in the joint tradition of political science and public administration and, more generally, recognizes and encourages scholarship in public administration.

Award Committee: Sharon Mastracci, Chair, University of Utah; Jerrell Coggburn, North Carolina State University; Charles Gossett, California State University, Sacramento.

\section{Recipient: J. Edward Kellough, University of Georgia}

Citation: The American Political Science Association (APSA) is proud to confer the 2019 John Gaus award upon Professor J. Edward Kellough for his "lifetime of exemplary scholarship in the joint tradition of political science and public administration." Dr. Kellough is a professor at the University of Georgia School of Public and International Affairs and is a fellow of the National Academy of Public Administration.

Professor Kellough received endorsements for this award from numerous scholars in public administration and political science. One recommendation notes that "For several decades, he has served as a top scholar and professional leader in public sector human resources management and in public management more generally.

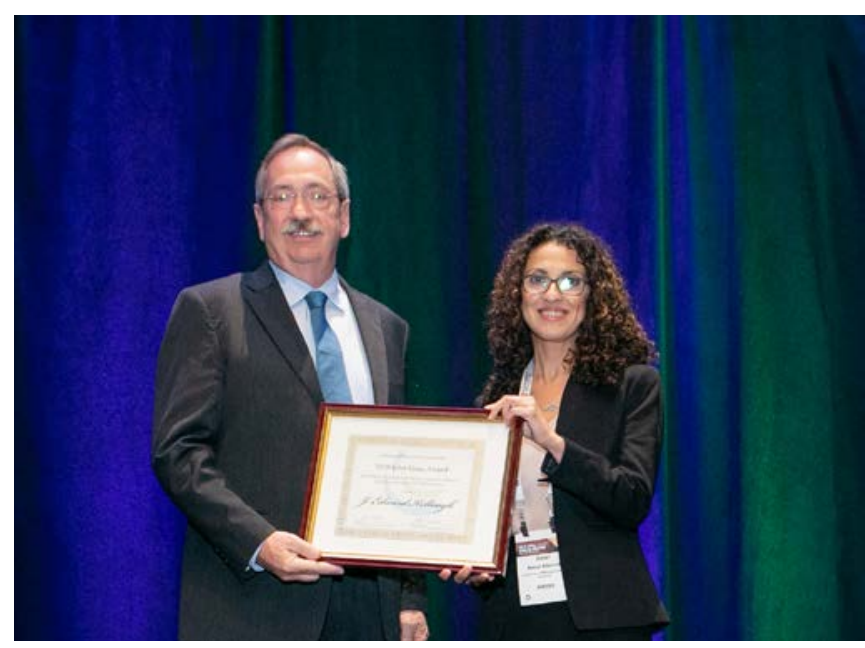

J. Edward Kellough (left) receives the John Gaus award from program cochair Amel Ahmed (right) 
He has been especially influential through his research and leadership on questions of affirmative action, representative bureaucracy, diversity, civil service reform, and related issues." Another observes that professor Kellough has tackled the most important issues in our fields, and that his book, Understanding Affirmative Action, presents one of the very best discussions on that topic by a public administration scholar. The book received the Best Book Award from the ASPA Section on Personnel Administration and Labor Relations. It extends his work in an earlier book on federal equal employment opportunity." And a third nominator underscores Professor Kellough's longevity and impact: "In the last 32 years, he has published four books, 44 peer-reviewed articles, 19 book chapters and nine encyclopedia entries... his textbook, The New Public Personnel Administration (coauthored by Lloyd Nigro and Felix Nigro), is now in its seventh edition. This text is Dr. Kellough's most frequently-cited work, though his scholarship on gender and race discrimination in public sector employment and on merit pay are also foundational contributions to the field."

Professor Kellough has mentored generations of scholars in political science and public administration and his scholarly achievements exemplify the lifetime of excellent scholarship that APSA envisions for this award.

\section{HUBERT H. HUMPHREY AWARD}

The Hubert H. Humphrey Award is awarded annually in recognition of notable public service by a political scientist. The award is intended to honor former Vice President Humphrey's distinguished career and life of public service.

Award Committee: Edie Goldenberg, Chair, University of Michigan, Ann Arbor; Kathryn Harrison, University of British Columbia; James Thurber, American University.

\section{Recipient: Thomas E. Mann, The Brookings Institution}

Citation: Dr. Thomas E. Mann earned his BA at the University of Florida and his MA and $\mathrm{PhD}$ at the University of Michigan, all in political science. He came to Washington, DC, in 1969 on a congressional fellowship, working in the offices of Senator Philip A. Hart and Representative James G. O'Hara. He served as executive director of the American Political Science Association (1981-1987) before moving to the Brookings Institution as Director of Governmental Studies (1987-1999) and the W. Averell Harriman Chair (1991-2014).

Dr. Mann is a fellow of the American Academy of Arts and Sciences and a member of the Council on Foreign Relations. He was honored with both the Frank J. Goodnow and Charles E. Merriam Awards of the American Political Science Association.

A prolific author, a university teacher, a pollster, a consultant, an expert witness, the former chair of the Board of Overseers of the National Election Studies, a frequently sought out lecturer in the United States and abroad, and a regular contributor to news stories as well as a commentator on television and radio, Dr. Thomas Mann continues to demonstrate an extraordinary commitment to political science, public policy, and public service. In addition to more than a dozen books, including two New York Times best sellers, Dr. Mann has also written numerous scholarly articles and opinion columns on a wide range of topics in American politics, including elections, campaign finance, political parties, Congress, the presidency, and public policymaking.

For his extraordinary achievements and exemplary commitment to scholarship, good governance and public service, Dr. Thomas E. Mann is truly deserving of the Hubert H. Humphrey Award.

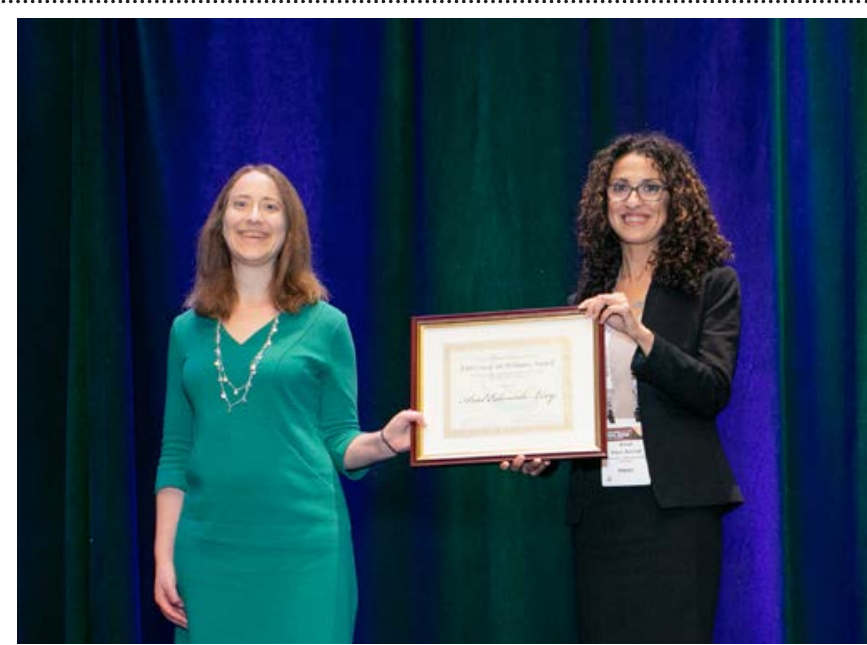

Ariel Edwards-Levy (left) receives the Carey McWilliams Award from program cochair Amel Ahmed (right).

\section{CAREY MCWILLIAMS AWARD}

The Carey McWilliams Award is given annually to honor a major journalistic contribution to our understanding of politics. The winner should have a distinguished public service career in media and political science and should illumine certain key elements identified with McWilliams, which include intellectual forthrightness and political independence.

Award Committee: Regina Lawrence, Chair, University of Oregon; Marion Just, Wellesley College; Dave Karpf, George Washington University.

\section{Recipient: Ariel Edwards-Levy, Huffington Post}

Citation: Ariel Edwards-Levy is a reporter and polling director at the Huffington Post, where she runs their polling partnership with You Gov, producing and explaining opinion data to yield insights on politics. In the current election season, her reporting has included topics like "Not All Democratic Voters are Looking for the Next Obama" and "'Undecided' Is Still the Real Democratic Frontrunner." Her smart use of polling data is evident both in her reporting and on her lively Twitter account. A nomination letter on her behalf notes that Edwards-Levy "issues an important caveat to runaway horse race journalism with sober reminders about what polls can and cannot tell us" and describes her as "one of the few voices of reason in an otherwise poll-crazy world of political journalism."

The committee finds Edwards-Levy's work timely and important and richly deserving of the Carey McWilliams award. Edwards-Levy has already distinguished herself as the kind of scholar this award was designed to recognize, whose work illuminates general principles of the social and political sciences and exhibits intellectual forthrightness and political independence.

\section{CHARLES E. MERRIAM AWARD}

The Charles E. Merriam Award is presented biannually to recognize a person whose published work and career represent a significant contribution to the art of government through the application of social science research.

Award Committee: Meira Levinson, Chair, Harvard University; Martin Gilens, University of California, Los Angeles; Frances Lee, University of Maryland. 


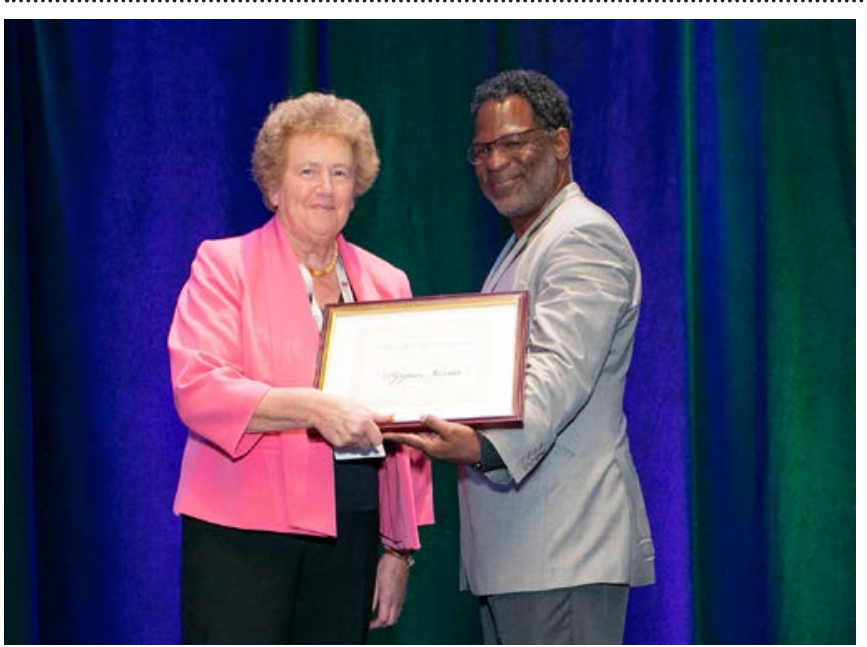

Pippa Norris (left) receives the Charles E. Merriam Award from program cochair Christopher Sebastian Parker (right).

\section{Recipient: Pippa Norris, Harvard University}

Citation: The Charles E. Merriam Award for 2019 goes to Pippa Norris, the Paul F. McGuire Lecturer in Comparative Politics at Harvard University and the ARC Laureate Fellow and professor of government and international relations at the University of Sydney.

Professor Norris exemplifies the rigorous application of social science to the art of government. Her scholarly work focuses on electoral integrity, democratic governance, political communication, and gender politics. She has been a prolific scholar, with over 50 books and hundreds of book chapters and journal articles.

In addition to her scholarly contributions, Professor Norris has used her expertise to advance democracy and improve elections in the U.S. and around the world. In 2012 she established the Electoral Integrity Project, an independent research project that focuses on why elections fail, why this matters, and what can be done to strengthen electoral integrity. The Electoral Integrity Project works with local teams of researchers in Mexico, Russia and India, as well as with international agencies including UN Women, the United Nations Development Program, the European Union, the Australian Electoral Commission, the Carter Center, the Association of European Election Officials, the United Nations Department of Political Affairs, USAID, and the International Institute for Democracy and Electoral Assistance.

Professor Norris has also served as director of the Democratic Governance Group at the United Nations Development Program in New York and as an expert consultant for many international bodies including the UN, UNESCO, UN Women, the Council of Europe, the World Bank, the National Endowment for Democracy, the Australian Electoral Commission, and the UK Electoral Commission.

Professor Norris' accomplishments have been widely recognized and celebrated as indicated by the many prestigious awards she has received. But the Merriam Award is a particularly fitting tribute to Professor Norris, given her extensive contributions to real-world democratic governance. At a time when democracy is under threat around the world, Professor Norris' commitment to strengthening democratic institutions is more critically important and more urgently needed than ever. We are delighted to be able to recognize Professor Norris' outstanding work with this year's Charles E. Merriam Award.

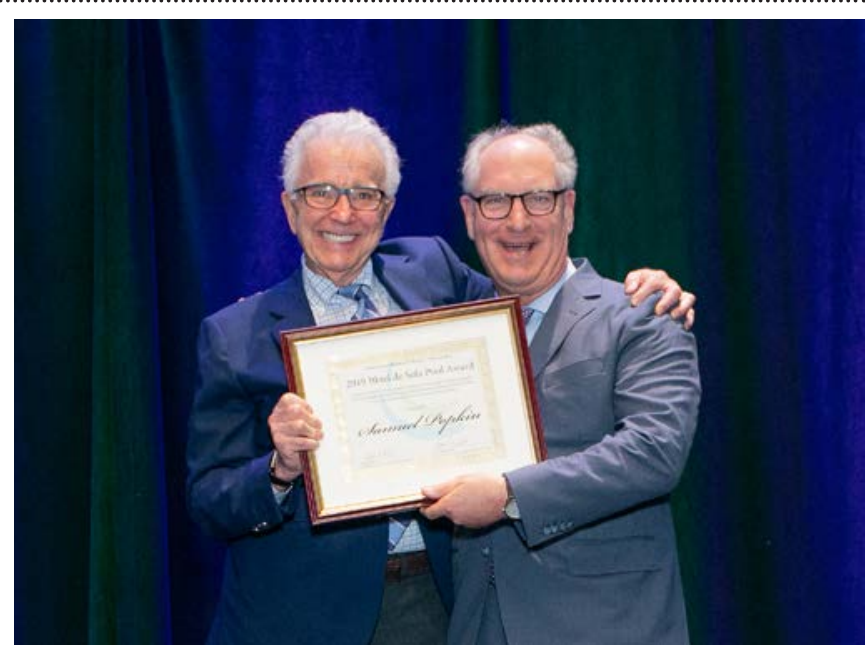

Samuel Popkin (left) accepts the Ithiel de Sola Pool Award from Adam de Sola Pool (right).

\section{ITHIEL DE SOLA POOL AWARD}

The Ithiel de Sola Pool Award and Lectureship is awarded triennially to a scholar whose research explores a broad range of fields pursued by Ithiel de Sola Pool including political theory, political behavior, political communication, science and technology policy, and international affairs.

Award Committee: Shanto Iyengar, Chair, Stanford University; Jeffrey Abramson, University of Texas, Austin; Barbara Pfetsch, Free University of Berlin.

\section{Recipient: Samuel Popkin, University of California, San Diego}

Citation: The committee unanimously concluded that the award should go to Samuel Popkin, professor emeritus at the University of California, San Diego. It pleased us greatly to grant the award to Professor Popkin as he is a former student of Dr. Pool, having studied under him at MIT. Professor Popkin's scholarly career-much like Pool's-has impacted multiple subfields of the discipline and proven influential both within the academy and the broader practitioner community.

Professor Popkin's dissertation used survey data, well before the use of such data was commonplace, to predict the outcomes of presidential elections. As described in Candidates, Issues, and Strategies: A Computer Simulation of the 1960 and 1964 Presidential Elections (1964), the authors (Pool, Abelson, and Popkin) developed a typology of voters based on their distinctive demographic attributes (e.g., upper-income versus lower-income). They next merged the demographic profiles with voters' preferences on a variety of salient political issues. Drawing from social psychological theory (Abelson was an eminent psychologist), the authors derived a series of theoretical expectations concerning the vote choices of the demographic and issue clusters they had identified. Finally, they used the combination of the demographic and issue-based typology to simulate the outcome of the 1960 and 1964 elections. Remarkably, their simulations provided more accurate than pre-election polls. This book is generally recognized as pathbreaking in its inter-disciplinary orientation and innovative methodology.

Popkin's next project led him to Vietnam to study the behavior of Vietnamese peasants. In The Rational Peasant (1979), Popkin used ethnographic methods to document the importance of economic 
self-interest in peasants' decision making. The book introduced a "political economy" perspective to the study of comparative politics in general and the study of peasant mobilizations in particular. Popkin, who based his interpretations on several years of interviewing in Vietnam and then scouring historic documents, noticed that peasants often took advantage of opportunities for personal advancement. To test his argument, Popkin analyzed the strategies used by groups-both religious and political-that mobilized peasants during the colonial period. What they shared was not a vision of restoration, but an organizational structure that provided peasants with an opportunity to break from their feudal past. Markets do not enslave peasants, Popkin concluded, they enable peasants to escape from oppression.

Popkin is best known for the next phase of his career, including landmark studies of political campaigns and their effects on voters. In The Reasoning Voter (1991), Popkin synthesized insights derived from cognitive and social psychology, mass communication research, and the by now burgeoning field of political behavior to develop a theory of "low information rationality." In essence, Popkin demonstrated that despite their general naiveté concerning the details of public policy, voters are naturally adept at using the snippets of information they encounter over the course of a campaign to derive a sense of where the candidates stand on the matters of concern to them.

The Reasoning Voter is recognized as a tour de force. It profoundly impacted the academic study of political campaigns, as well as the behavior of campaign consultants themselves. James Carville, the architect of Bill Clinton's upset victory over President George Bush in 1992, had this to say about the book: "If you're preparing to run a presidential campaign and only have time to read one book, make sure you read Sam Popkin's The Reasoning Voter. If you have time to read two books, read The Reasoning Voter twice."

On the basis of his inter-disciplinary research trajectory, his multiple contributions to the study of political campaigns and voting, and his intellectual connections to Pool, the committee is confident that Professor Samuel Popkin is a truly deserving winner of the Ithiel de Sola Pool Award.

\section{HANES WALTON, JR. AWARD}

The Hanes Walton, Jr. Career Award is given biannually in recognition of a political scientist whose lifetime of distinguished

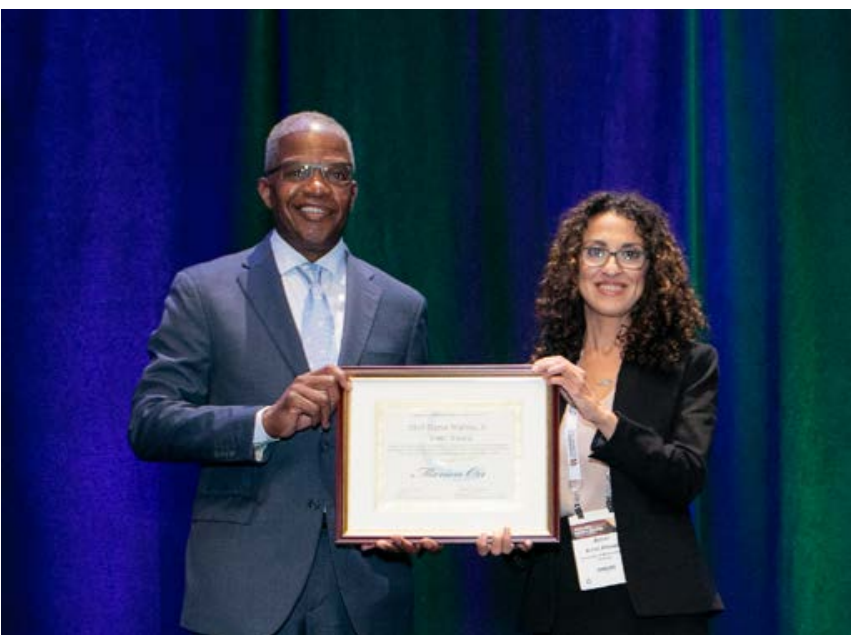

Marion Orr (left) receives the Hanes Walton, Jr. Award from program cochair Amel Ahmed. scholarship has made significant contributions to our understanding of racial and ethnic politics and illuminates the conditions under which diversity and intergroup tolerance thrive in democratic societies.

Award Committee: Christina Greer, Chair, Fordham University; Pearl K. Dowe, University of Arkansas; Ravi Perry, Virginia Commonwealth University.

\section{Recipient: Marion Orr, Brown University}

Citation:We are delighted to present the 2019 APSA Hanes Walton, Jr. Career Award to Dr. Marion Orr, Frederick Lippitt Professor of Public Policy and professor of political science and urban studies at Brown University. Previously, Orr was a member of the political science faculty at Duke University. Since his arrival at Brown University, Dr. Orr has chaired the department, served as director of the A. Alfred Taubman Center for American Politics and Policy, mentored undergraduate and graduate students across several disciplines-all while authoring/editing seven books and numerous articles in journals ranging from political science, policy, education, and urban politics/affairs/studies. We are pleased to add the APSA Hanes Walton, Jr. Career Award to this impressive list of longstanding service to the profession.

Professor Orr served as president of the APSA's Organized Section on Urban Politics. From 2000-2006 he was an elected member of the Governing Board of the Urban Affairs Association (UAA), an international organization devoted to the study of urban issues. In 2005-2006 he served as Chair of UAA's Governing Board. Dr. Orr has also served as a member of the executive councils of the APSA and the National Conference of Black Political Scientists.

In addition to Dr. Orr's remarkable track record of teaching and mentoring undergraduates and graduate $\mathrm{PhD}$ students at Brown University, he has also translated his scholarship into prestigious fellowships from the Ford Foundation and the Brookings Institution, and the University of California, Berkeley, to name just a few. His scholarship has been widely praised, cited, and the recipient of some of the discipline's most prestigious awards including the Aaron Wildavsky Award, the APSA Urban Politics Section's Best Book Award, the Miriam Mills Award, and the Rodney Higgins' Best Paper Award. This is not an exhaustive list of Professor Orr's fellowships and awards.

As one of Dr. Orr's former students and academic collaborators noted in his letter, "Yet, for all of his important scholarly contributions, perhaps Dr. Orr's greatest contribution to the study of racial and ethnic politics has been his unrelenting commitment to the study of urban politics. While many would-be urbanists have been discouraged by their mentors from pursuing careers as scholars of urban politics, Marion Orr has mentored a generation of urban scholars. He has maintained that the understanding of racial and ethnic politics in the US is impossible without an understanding of urban politics."

His students, colleagues and recommenders praise Dr. Orr as an exceptional and supportive mentor, and as a devoted, inspiring and impactful teacher. As one of his former students wrote, "Marion Orr has dedicated his career to mentoring undergraduate students, graduate students, and junior faculty. I have been a beneficiary of his commitment to mentorship and advocacy. I would not be a political scientist [if not for] Marion Orr."

Inspired by Dr. Walton's instruction while an undergraduate student at Savannah State College (now university), we are grateful for Dr. Orr's continued commitment to impactful research in 
American politics. An entire generation of urban scholars already lauds Dr. Orr for his commitment to shaping and developing them and the next generation of scholars. Orr's mentorship has produced thinkers in a variety of subfields and academic citizens dedicated to the discipline of political science and the politics of community.

\section{Book Awards}

\section{APSA-IPSA THEODORE J. LOWI FIRST BOOK AWARD}

The APSA-IPSA Theodore J. Lowi First Book Award is given annually for the best first book in any field of political science, showing promise of having substantive impact on the overall discipline. Support for the Lowi award is contributed by APSA and IPSA in alternating years.

Award Committee: Desmond King, Chair, University of Oxford; Rodney Hero, Arizona State University; Ferdinand Müller-Rommel, Leuphana University Lüneburg.

Recipient: Stephanie J. Rickard, London School of Economics

Citation: The award committee was unanimous in its decision to award the Theodore J. Lowi First Book Award for 2019 to Stephanie J. Rickard. Dr. Rickard is an associate professor in the Department of Government at the London School of Economics. Her research focuses broadly on international political economy with a special focus on the politics of trade, uneven geographic patterns of economic activity and the effects of political institutions on economic policies. She earned her PhD at the University of California, San Diego and her BA at the University of Rochester. Her work has appeared in International Organization, Journal of Politics, British Journal of Political Science, and Comparative Political Studies. She is on the editorial board of International Organization.

Her first book, Spending to Win:Political Institutions, Economic Geography, and Government Subsidies (2018, Cambridge University Press) investigates why governments selectively target economic benefits, like subsidies, to businesses. It is meticulously-researched, empirically rich and theoretically innovative. Drawing on interviews with government ministers and civil servants, and a host of primary sources, Spending to Win argues convincingly that economic policy results from a combination of electoral institutions and economic geography.

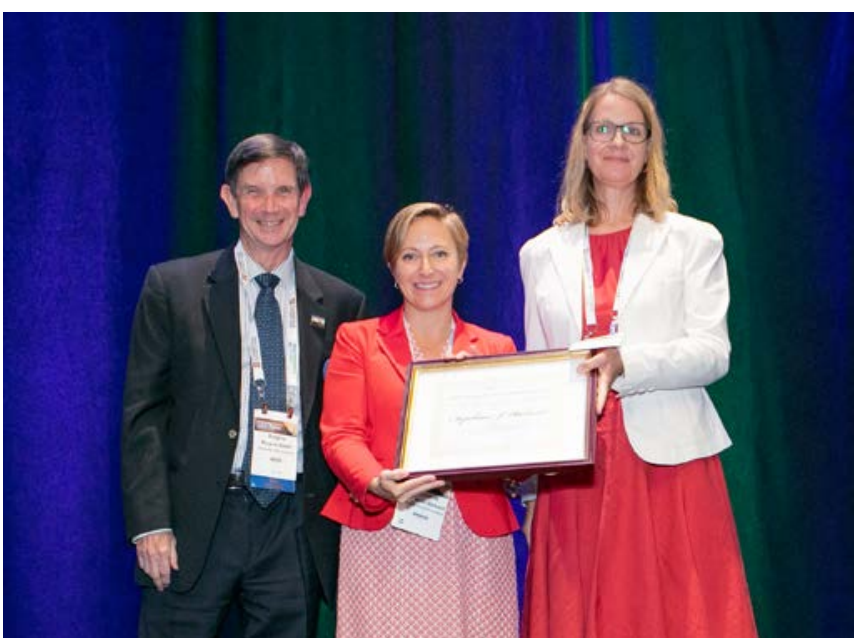

Stephanie J. Rickard (center) receives the APSA-IPSA Theodore J. Lowi Award from APSA president Rogers Smith (left) and IPSA president Marianne Kneuer (right).

\section{RALPH J. BUNCHE AWARD}

The Ralph Bunche Award is given annually for the best scholarly work(s) in political science that explores the phenomenon of ethnic and cultural pluralism.

Award Committee: Claire Jean Kim, Chair, University of California, Irvine; Maarten Vink, Maastricht University; Betina Wilkinson, Wake Forest University.

\section{Recipient: Michael Hanchard, University of Pennsylvania}

Citation: The recipient of the Ralph Bunche Award for 2019 is Dr. Michael Hanchard, whose new book, The Spectre of Race: How Discrimination Haunts Western Democracy, is an outstanding contribution to political science scholarship on racial and ethnic domination and hierarchy. It asks profound questions, is wideranging and ambitious in its arguments, and speaks to the most urgent political-ethical dilemmas of our time. Dr. Hanchard's particular concern is the intimate relationship between democracy, on the one hand, and social and political inequality, on the other-a relationship he traces to classical Athens, where the first democracy was built upon a foundation of domination and exclusion, as slaves, metics, and women were kept out of the political community. Inequality was not anomalous in but rather foundational to democracy from the very beginning, Dr. Hanchard points out, and democracies have all been what Robert Dahl calls polyarchic regimes, or relatively but incompletely democratized regimes.

Demonstrating the singular power of comparative analysis, Dr. Hanchard substantiates these claims through a sweeping analysis of nineteenth and twentieth-century democratic regimes in Latin America, the Caribbean, Europe, and North America. Whether it was Gran Columbia or Guyana in the period after gaining independence, or France and Britain during the decolonization era, all of these democracies-with the shining exception of Haiti-depended upon the demarcation of and institutionalization of racial, gendered, religious and ethno-national hierarchies to determine who was allowed to access citizenship and its privileges and who was excluded from these. With all this in mind, Dr. Hanchard calls upon comparativists within political science to rethink the ethnocentric categories that imagine the West as the ideal standard of democracy to which

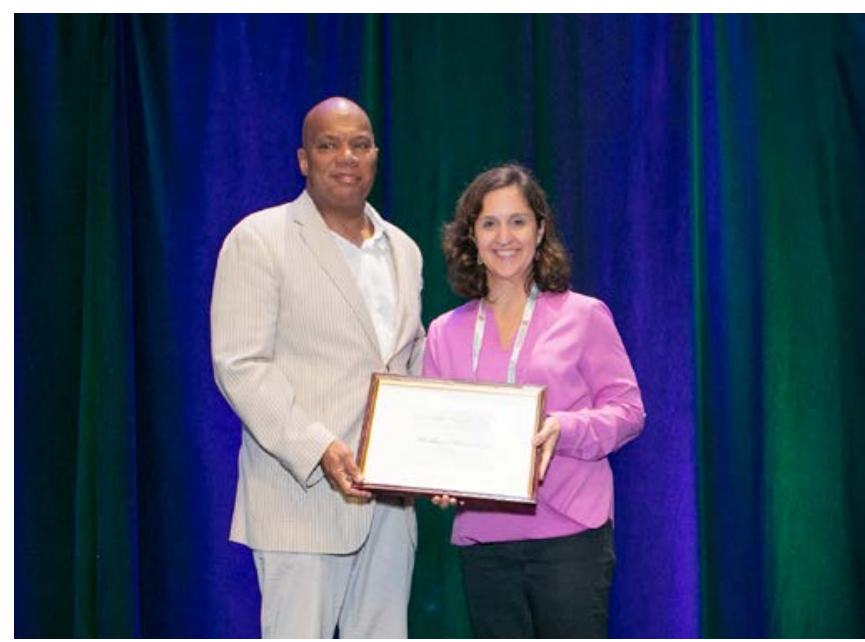

Michael Hanchard (left) receives the Ralph J. Bunche Award from award committee member Betina Wilkinson (right). 
the rest of the world should aspire. He calls upon them to engage racial and ethno-national hierarchies more seriously by considering more fully the impact of slavery, colonialism, and imperialism on both the so-called developed and developing nations. There is a mutual entanglement here that requires deep historical and contextual analysis and that cannot be captured by econometrics, game theory, and mathematical modeling.

The Spectre of Race ends with a postscript about the events in Charlottesville in 2017, reminding us that today's resurgence of farright populism, authoritarianism, and white supremacy in the US and elsewhere across the globe is nothing new at all, but a continuation of democracy's long association with and dependence upon racial and ethno-national hierarchies. It is a sobering message, but one that helps us to reckon with the moment we find ourselves in.

\section{ROBERT A. DAHL AWARD}

The Robert A. Dahl Award recognizes an untenured scholar(s) who produced scholarship of the highest quality on the subject of democracy, including books, papers, and articles.

Award Committee: Melissa Schwartzberg, Chair, New York University; Jill Simone Gross, Hunter College; Daniel Treisman, University of California, Los Angeles.

\section{Recipient: Alexander Hertel-Fernandez, Columbia University}

Citation: We are delighted to present the 2019 Robert A. Dahl Award to Alexander Hertel-Fernandez for his book, Politics at Work: How Companies Turn Their Workers into Lobbyists (Oxford University Press, 2018). In Politics at Work, Hertel-Fernandez examines how American employers seek to mobilize their workers in support of policies and candidates, taking over from the declining labor movement unions' traditional role in political recruitment. Although scholars of comparative politics have studied how business executives mobilize workers to vote and rally for favorite candidates in Russia, Indonesia, and Algeria, few have analyzed such recruitment tactics in the United States, where corporate influence is usually seen as working through lobbying and campaign contributions. Drawing on surveys of workers, corporate managers, and congressional staff, as well as interviews, Hertel-Fernandez argues that power asymmetries between managers and workers enable the former to recruit the latter for their companies' political aims. Indeed, this

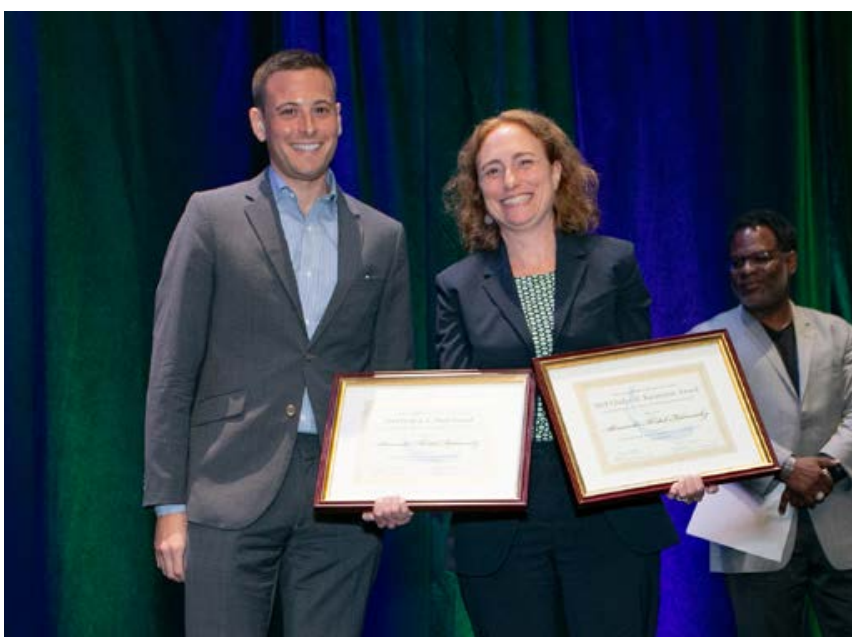

Alexander Hertel-Fernandez (left) receives the Robert A. Dahl and Gladyn M. Kammerer awards from Dahl Award committee chair Melissa Schwartzberg (right). mobilization works most effectively in highly asymmetrical workplaces, where workers are fearful of job loss or wage/hour cuts, and when they believe their managers have the ability to monitor their political views and to retaliate against them. Employee mobilization constitutes yet another form of coercion deriving from what Dahl himself identified as the hierarchies of corporate capitalism, and to which Dahl and Hertel-Fernandez alike propose workplace democracy as a partial remedy. Accessibly written and powerfully argued, Politics at Work merits a wide public audience.

\section{GLADYS M. KAMMERER AWARD}

The Gladys M. Kammerer Award is given annually for the best book published during the previous calendar year in the field of US national policy.

Award Committee: Tali Mendelberg, Chair, Princeton University; John Berg, Suffolk University;Jack Nagel, University of Pennsylvania.

\section{Recipient: Alexander Hertel-Fernandez, Columbia University}

Citation: The winner of the 2019 Kammerer award is Politics at Work (Oxford University Press) by Alexander Hertel-Fernandez. The book masterfully documents the sharp rise in American businesses' efforts to engage their workers in politics and shows how and why it matters for what employees-and congressional staffers attuned to the threat of district job loss-do. It argues persuasively that these efforts may be fundamentally changing politics and policy. Using an impressive variety of appropriate methods, including experiments with employees, congressional staffers, and managers, as well as qualitative interviews, it breaks new ground as it examines an important but overlooked problem: the renewed, robust grass-roots power of business in American democracy. The book situates the sky-rocketing increase in employer mobilization in the context of policy changes that may have prompted it and concludes with possible policy responses to profoundly problematic employer influence over employees who are monitored by their employer, fear for their jobs, and left economically vulnerable. The book is also extremely well-written. Of the nearly 60 books submitted for this competition, it is perhaps the most complete, well-defined, and original inquiry into a significant aspect of US national policy.

\section{BENJAMIN E. LIPPINCOTT AWARD}

The Benjamin E. Lippincott Award is presented biannually to recognize a work of exceptional quality by a living political theorist that is still considered significant after a time span of at least 15 years since the original date of publication. Support contributed by the University of Minnesota.

Award Committee: Andrew Norris, Chair, University of California, Santa Barbara; Joan Cocks, Mount Holyoke College; Daniel Lee, University of California, Berkeley.

\section{Recipient: Philip Pettit, Princeton University}

Citation: The Benjamin E. Lippincott award is bestowed upon a living political theorist for a work of exceptional quality that is still considered significant at least 15 years after its initial publication date. The winner of the 2019 Lippincott award is Philip Pettit's 1997 Republicanism: A Theory of Freedom and Government. Republicanism is an exemplary work in the history of political thought, in normative political theory, and in institutional design. Pettit demonstrates that the distinction between positive and negative liberty familiar from Hobbes, Rousseau, Kant, Hegel, and Constant, and popularized by Isaiah Berlin, oversimplifies and impoverishes the conceptual 
distinctions available to ancient and early modern thinkers. In particular, it obscures what Pettit calls "liberty as non-domination," a political ideal originating in the republican tradition of politics associated with such thinkers as Cicero, Machiavelli, and Milton. Unlike a positive conception of liberty, this idea does not commit free individuals to a positive set of goods or actions, but neither does it collapse liberty into the mere absence or "negation" of active coercion or interference. Neoliberals such as Milton Freidman and Friedrich von Hayek define liberty as the absence of coercion in part because this allows them to identify a free society as one with a weak state and a largely unregulated market economy. But such a society may still be rife with what Pettit calls "domination"- - the capacity of one to interfere in the affairs of another on an arbitrary basis-and thus hardly free. As Pettit demonstrates, one can be dominated in truly oppressive ways even if one is not actually subject to interference, and one can be subject to "coercive" governmental regulation that does not dominate. Hence a free society is one in which markets and powerful market actors are constrained by a state dedicated to the liberty of all of its members, including its weakest and less respected members. Pettit patiently works out the practical implications of this view for political institutions and behavior, producing a book that is politically relevant as well as rigorous and intellectually masterful. The influence of this work in such diverse areas of scholarship as constitutional theory, democratic theory, international law, global justice, and, more recently, post-colonial theory serves to reinforce the committee's judgment that Republicanism has become a classic of political theory.

\section{VICTORIA SCHUCK AWARD}

The Victoria Schuck Award is given annually for the best book published on women and politics. Established to honor Victoria Schuck's life-long commitment to women and politics, this prize recognizes and encourage research and publication in this field. Schuck earned her $\mathrm{PhD}$ in 1937 from Stanford University and played a leading role in opening doors for women in the profession. She was not only an outstanding mentor for women, but her service in senior administrative roles at Mount Holyoke College and Mount Vernon College opened doors for future generations of women leaders.

Award Committee: Eileen McDonagh, Chair, Northeastern University; Dara Kay Cohen, Harvard University; Samantha Majic, CUNY, John Jay College.

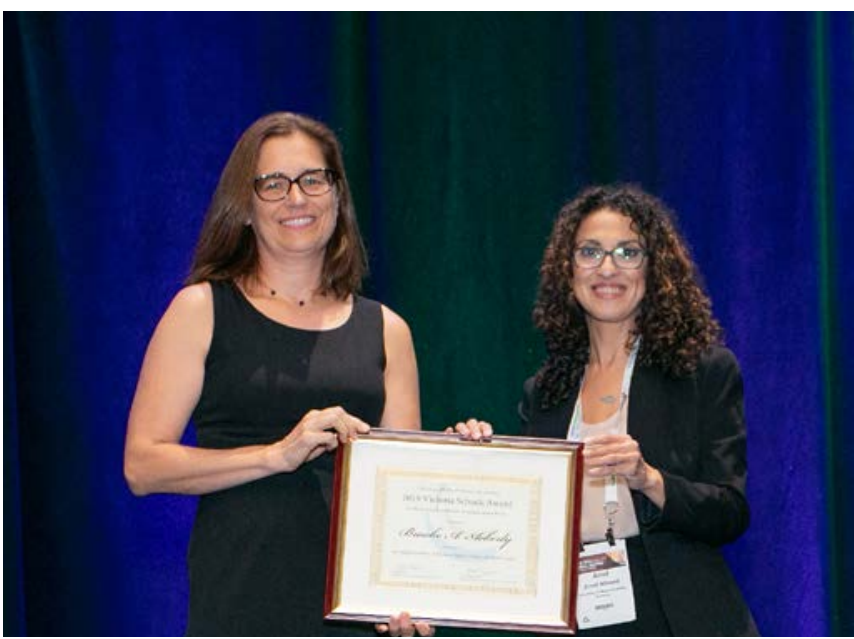

Brooke A. Ackerly (left) is presented with the Victoria Schuck Award by program cochair Amel Ahmed (right)
Recipient: Brooke A. Ackerly, Vanderbilt University

Citation:In this path-breaking book, Just Responsibility: A Human Rights Theory of Global Justice, author Brooke Ackerly defines injustice as primarily a political rather than a moral problem. In so doing, she reconfigures basic epistemological and feminist perspectives, arguing that we must concentrate on what constitutes injustice itself, rather than merely its consequences. In particular, she advances new ways of thinking about injustice by centering on the question: "What should we do about it?" Using the method of feminist grounded normative theory, she expertly answers that question by identifying and theorizing the root causes of injustice; explaining why experience-based theory matters; and showing how we can do it in both our research and in our everyday lives. She thereby integrates philosophy and action in a way that is empirically-informed and attuned to the voices of those at the forefront of global struggles for rights and justice. As a result, her remarkable book is anchored on a vital theoretical standpoint and rigorous interpretative exposition. Also important, Just Responsibility is accessible to a wide range of audiences, thereby ensuring that this book's pivotal contributions will provide a foundation for work continued by many.

\section{WOODROW WILSON FOUNDATION AWARD}

The Woodrow Wilson Award is given annually for the best book on government, politics, or international affairs. The award, formerly supported by the Woodrow Wilson Foundation, is sponsored by Princeton University.

Award Committee: Kenneth Wong, Chair, Brown University; Zehra Arat, University of Connecticut; Julianna Pacheco, University of Iowa.

\section{Recipient: Kristina Miler, University of Maryland}

Citation: Does representational democracy work for the 60 million people living in poverty or near poverty in the United States? Is the US Congress paying attention to the poor? In Poor Representation: Congress and the Politics of Poverty in the United States, Kristina C. Miler offers a groundbreaking analysis on the general lack of Congressional actions to address the interest of the poor in our representational democracy. This book challenges the effectiveness of our representational democracy in practice and engages us in a

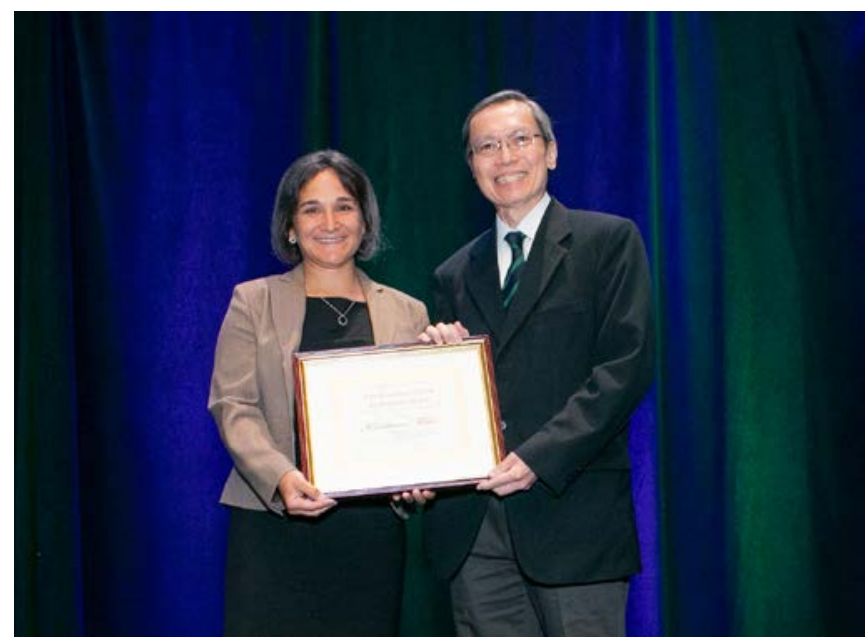

Kristina Miler (left) receives the Woodrow Wilson Foundation Award from award committee chair Kenneth Wong (right). 
critical reexamination of our normative and empirical understanding of representative governance. The study meticulously differentiates interest-based from preference-driven politics and conducts an outstanding investigation across a broad range of legislative, representational actions beyond Congressional votes and policy outcomes. Further, Miler synthesizes multiple theoretical perspectives on representation, including aggregate, dyadic, and surrogate, in addressing issues affecting the poor. Finally, Miler's findings call our attention to the challenge of representational democracy, including the lack of diversity of Congressional members and the polarization of poverty issues between the two major parties. These theoretical, empirical, and policy contributions are path-breaking and highly relevant beyond the political system in the US.

\section{Dissertation Awards}

\section{GABRIEL ALMOND AWARD}

The Gabriel A. Almond Award is given annually for the best dissertation in the field of comparative politics. The award was created in recognition of Gabriel Almond's contributions to the discipline, profession, and association. Almond's scholarly work contributed directly to the development of theory in comparative politics and brought together work on the developing areas and Western Europe that prevented splintering into an array of disparate areas studies.

Award Committee: Vivien Schmidt, Chair, Boston University; Amy Erica Smith, Iowa State University; Leonard Wantchekon, Princeton University.

Recipient: Andreas Wiedemann, Massachusetts Institute of Technology

Citation: The Committee for the Gabriel A. Almond Award for the Best Dissertation in Comparative Politics in 2019 unanimously selected Andreas Wiedemann's “Indebted Societies: Modern Labor Markets, Social Policy, and Everyday Borrowing." This masterful dissertation brings into conversation bodies of literature that have not previously been effectively integrated, demonstrating how credit and social welfare regimes interact in shaping citizens' life trajectories, responses to risk, and political attitudes in advanced industrial democracies. Wiedemann's study is elegant, rigorous, and innovative,

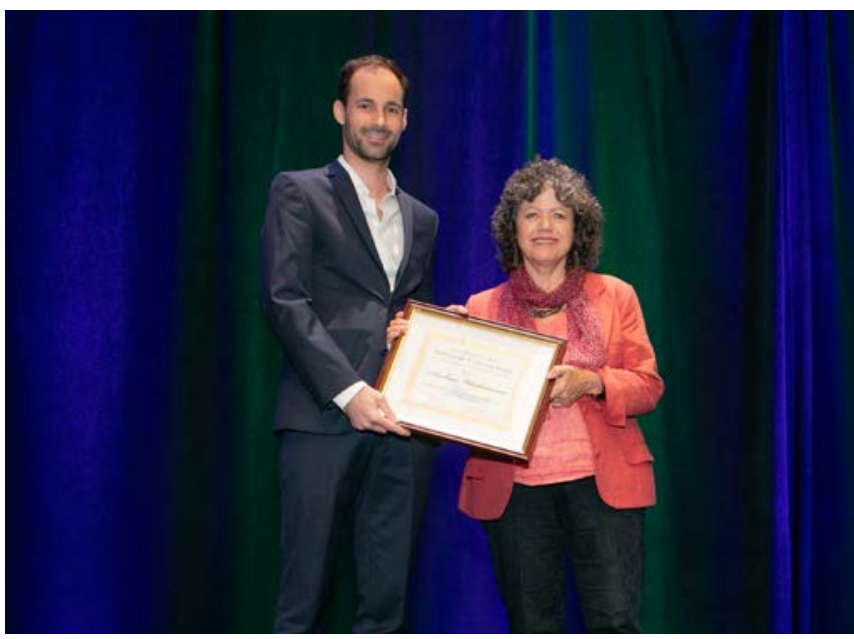

Andreas Wiedemann (left) accepts the Gabriel A. Almond award from award committee chair Vivien Schmidt (right). providing a clear and convincing argument that is exceptional in its ability to speak to multiple audiences across political science. Andreas' work is truly comparative in the broadest sense of the word, first by bridging the American Politics/Comparative Politics divide with his persuasive case studies of three countries, the United States, Denmark, and Germany; second by bridging the quantitative/ qualitative divide, by integrating these case studies with analysis of original cross-national survey data from wealthy democracies. The linkages between financial markets, national economies, and different families of welfare states are especially well drawn and brilliantly elucidated. Notably, although focused on advanced democracies, the dissertation is so theoretically interesting and rich that it also suggests wide-ranging theoretical and empirical implications for scholarship on middle-income and lower-income states. Finally, the work is impressive for its contributions to literatures in political economy, political behavior, and comparative politics, and for its important insights into how we understand inequality within and across countries.

\section{WILLIAM ANDERSON AWARD}

The William Anderson Award is given annually for the best dissertation in the general field of federalism or intergovernmental relations and state and local politics. The award was set up in honor of William Anderson, former APSA president, who was a leading American authority in the areas of local government, public administration, intergovernmental relations and the history of political science. $\mathrm{He}$ did much to shape teaching and research in these fields not only at his own university, but throughout the country.

Award Committee:Jennifer Wallner, Chair, University of Ottawa; Lisa Miller, Rutgers University; Richard Winters, Dartmouth College.

\section{Recipient: Jacob Grumbach, University of California, Berkeley}

Citation: Linking the study of federalism to other areas of political science, "Polarized Federalism: Activists, Voters, and Resurgence of State Policy in the US" offers an innovative way of analyzing the evolution, workings, and implications of divided government. Empirically impressive and extremely timely, Grumbach investigates the cause and consequences of policy variation and policy polarization among the US states. Detailing policy change over time, this research exposes the ways in which changes in party organization

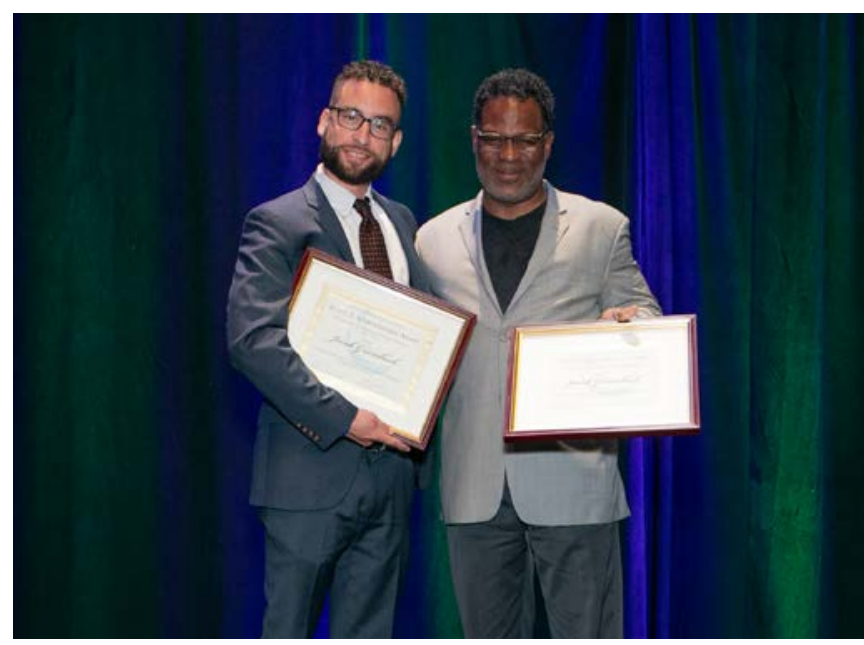

Jacob Grumbach (left) receives the William Anderson and E. E. Schattschneider awards from program cochair Christopher Sebastian Parker (right). 
are key to understanding the polarization of state policy over the past generation. Grumbach's work, moreover, also uncovers a new shift in the organization landscape-the remarkable and increasingly sophisticated coordination of activist groups. Tracking campaign contributions, Grumbach finds that since 2000, there has been a dramatic increase in the number of individual campaign donors connected to single issue and ideological activist organizations such as the NRA, Americans for Tax Reform, and Planned Parenthood. Put together, these transformations in the US state policy landscape have enabled and contributed to the polarization of state policies.

Grumbach's work also challenges the conventional view of the structure of federalism in the United States: "Rather than a decentralized federalist system with vertical differences across levels and horizontal differences across regions, American governmental institutions look increasingly like a single arena of partisan combat over public policy." Grumbach displays a remarkable set of methodological tools to complete this research. Chapter two, for example, entailed the building of a large dataset of state policies to estimate policy variation and polarization in the states since 1970. Tracking polarization over 16 issue areas, polarization can be seen in 14 but not in the key areas of education and criminal justice policy. Here is where Grumbach shows he is not content to simply count policies but also consider the substantive outcomes of state action declaring that "both Democratic and Republican state governments have driven the rise of mass incarceration in recent decades."

The committee warmly congratulates Grumbach on a dissertation that challenges conventional wisdom, offers a new means to explore and understand federalism, while tackling what is arguably one of the leading issues of American politics today.

\section{EDWARD S. CORWIN AWARD}

The Edward S. Corwin Award is given annually for the best dissertation in the field of public law. The Corwin award is for the best doctoral dissertation completed and accepted during that year or the previous year in the field of public law, broadly defined to include the judicial process, judicial behavior, judicial biography, courts, law, legal systems, the American constitutional system, civil liberties, or any other substantial area, or any work which deals in a significant fashion with a topic related to or having substantial impact on the American Constitution.

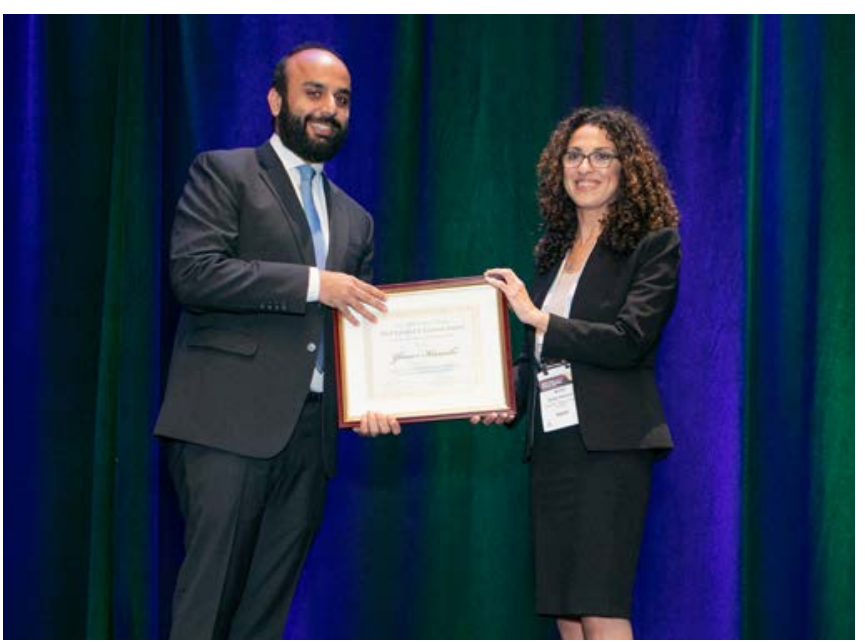

Yasser Kureshi (left) is presented with the Edward S. Corwin award by program cochair Amel Ahmed.
Award Committee: Melinda Gann Hall, Chair, Michigan State University; Justin Crowe, Williams College; Douglas Reed, Georgetown University.

\section{Recipient: Yasser Kureshi, Brandeis University}

Citation: In pathbreaking research, Yasser Kureshi of Brandeis University provides a fascinating theory of the conditions under which judiciaries act to contest the prerogatives of politically powerful militaries in authoritarian and post-authoritarian regimes. He then tests these broader theoretical constructs in the context of Pakistan. In doing so, Professor Kureshi accomplishes the extraordinary by, among other things, combining a rich and detailed historical analysis of judicial-military relations in Pakistan from 1947 through 2015 with an empirical evaluation of over 700 high court decisions from 1973 to 2015. The data sources are vast and varied, including law reviews, digests, and reporters; newspaper articles, judicial speeches, judicial biographies, bar association resolutions, and interviews with lawyers and retired judges. The results are profound: a deep contextual understanding of judicial-military relations in Pakistan, high-level theorizing about democratization and the conditions under which courts across the globe help to establish and maintain the rule of law, and empirical testing of the principle hypotheses derived from the theory, all in the same dissertation.

Professor Kureshi specifically points to the shift in judicial assertiveness toward the military in Pakistan as a direct consequence of a change in the audiences with which judges and courts interact. Judicial affinity toward the military diminished as audiences from which judges seek approval grew independent from the military, especially politically active bar associations. Professor Kureshi also documents the nuanced nature of the judiciary's response, showing that these new judicial actions toward curbing the military were contingent on the type of prerogative being challenged.

Overall, this dissertation provides a powerful theoretical explanation for judiciaries acting to bring powerful militaries under civilian control in authoritarian and post-authoritarian regimes. This exciting new work significantly expands and enhances the fields of judicial politics and comparative politics while providing a wealth of information about Pakistan. Without question, this dissertation represents the very best of political science scholarship focused on law and courts and thus is most deserving of the Edward S. Corwin Award.

\section{HAROLD D. LASSWELL AWARD}

The Harold D. Lasswell Award is given annually for the best dissertation in the field of public policy.

Award Committee: Kristin Goss, Chair, Duke University; Matt Levendusky, University of Pennsylvania; Brent Steel, Oregon State University.

\section{Recipient: Natália S. Bueno, Yale University}

Citation: We are pleased to award the 2019 Harold D. Lasswell Prize for the best dissertation in the field of public policy to "The Distributive Politics of Non-State Welfare Provision." The study advances a novel theory of welfare state provision-one that emphasizes the political relationship between elected officials, who make funding decisions about social services, and non-governmental organizations, which deliver them. The study develops clear hypotheses and uses a variety of qualitative, quantitative, and experimental data to carefully test them. The result is an original and important study that will be widely read and cited by scholars of both American and comparative public policy. 
The study's core argument is that non-state, nonprofit organizations that provide public services may see themselves as apolitical actors, but they are also deeply involved in distributive politics around the world. In 35 countries, these charitable organizations receive approximately $50 \%$ of their budgets from the government, and they use these monies to provide social services to voters. In implementing welfare state programs through nonprofits, governments are behaving seemingly irrationally because they are denying themselves the ability to claim credit for these benefits. Why wouldn't political leaders want to provide services directly through government agencies, thereby gaining the ability to benefit politically from these programs?

The answer, the author argues, is that routing social services via nonprofit organizations allows incumbents to deliver social services to areas governed by political opponents. If services were delivered via the local government, then the opposing party-which governs the local area-could simply claim the credit. But if the program flows through a nonprofit, voters will not give the local leaders credit for the program. So presidents and central governments use nonprofits to bypass local opposition politicians, avoiding the problem of credit hijacking.

The author provides a number of innovative tests of the argument by examining central government spending on social welfare programs in Brazil. The author finds that when the opposing party controls a city, the central government is more likely to direct resources there via nonprofit organization, rather than the mayor's office (and the reverse is true when a co-partisan sits in the mayor's office). This effect is particularly credible because the author uses a regression discontinuity design to look at close mayoral races, where an opposing party mayor just wins or loses, which allows the author to rule out other confounding effects.

The author also uses survey experiments to show that when the federal government disperses funds via a nonprofit organization, voters are less likely to give credit to the mayor than when the local government delivers the services directly. So by channeling money through nonprofits, the central government robs the opposition of the ability to claim credit for social benefits. In interviews with local nonprofit leaders, the author finds that organizations take these grants because they need the money and refusing them leads the government to shut out the organization from future grants. But nonprofit leaders also noted that in exchange for allowing them to

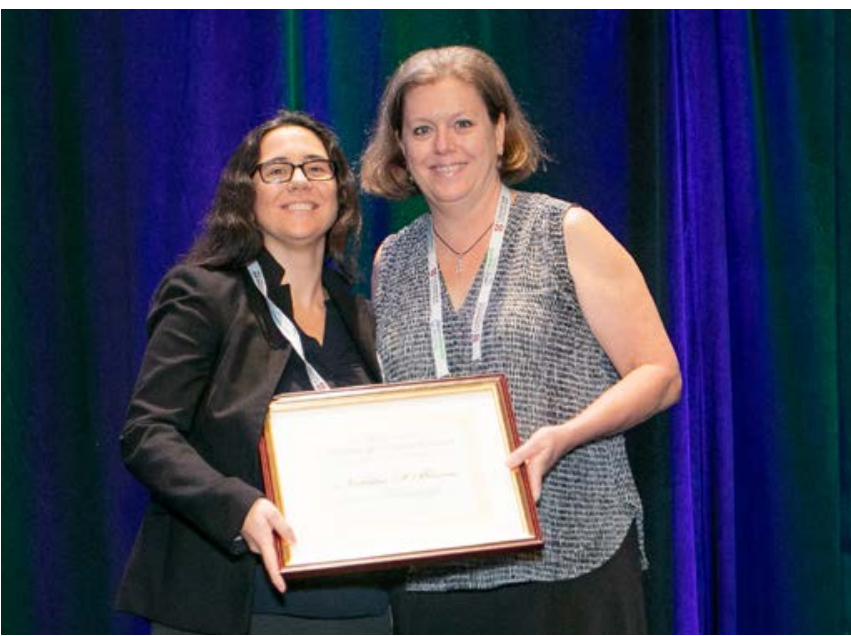

Natália S. Bueno (left) receives the Harold D. Lasswell award from award committee chair Kristin Goss (right). distribute these funds, local officials expected them to help with their next political campaign, and members of the organization are often called upon to become campaign volunteers. So, by channeling monies this way, central leaders not only prevent opposingparty rulers from credit-claiming, but also get a means of boosting campaign activism for co-partisans.

While the empirical evidence focuses on the Brazilian case, the argument is more general given the role that nonprofit organizations play around the globe, and hence it has broad-ranging implications for debates on distributive politics, clientelism, and social service delivery. We expect this dissertation will be widely read by scholars in both American and comparative politics, and it will become a future touchstone for others working in this area. For those reasons, we are proud to award this prize to "The Distributive Politics of Non-State Welfare Provision."

\section{E.E. SCHATTSCHNEIDER AWARD}

The E.E. Schattschneider Award is given annually for the best doctoral dissertation completed and accepted during that year or the previous year in the field of American government. This award was set up in honor of Elmer Eric Schattschneider, a former APSA president, and widely published and respected political scientist.

Award Committee: Robert Mickey, Chair, University of Michigan; Kristi Andersen, Syracuse University; MaryAnne Borrelli, Connecticut College.

\section{Recipient: Jacob Grumbach, University of California, Berkeley}

Citation: In "Polarized Federalism," Jake Grumbach explores the politics of policymaking in the American states. He shows that, since the 1970s, as congressional polarization soared, statelevel policymaking has diverged across the states. In a study of 135 policies across sixteen issue areas, Grumbach demonstrates, contrary to existing accounts, that partisan control of state legislatures increasingly has an outsize impact on policy outcomes across a range of issue areas. Moreover, these policies matter for residents' life-chances. Rather than producing a wide diversity of subnational politics, however, Grumbach shows that nationallevel coalitions have helped direct state-level policymaking, and are more important than state-level public opinion in determining policy. An analysis of campaign donations emanating from networks of activists points to the role of organized interests in bringing these coalitions to life. The cumulative effect of Grumbach's research is to suggest how we might knit together both national-level polarization and subnational policymaking, and points to how US politics have collapsed into a "single arena of partisan combat over public policy."

The committee found the dissertation methodologically sophisticated, analytically rich, well-written, and generally convincing. Grumbach carefully and skillful deploys a diverse array of evidence in order to answer an urgent set of questions about American democracy. The dissertation promises to enrich the subfield, and is a worthy recipient of this year's Schattschneider prize.

\section{KENNETH SHERRILL PRIZE AWARD}

Through APSA's Centennial Center for Political Science and Public Affairs, the Kenneth Sherrill Prize Award recognizes the best doctoral dissertation proposal for an empirical study of lesbian, gay, bisexual, or transgender (LGBT) topics in political science. The purpose of this prize is to encourage and enable empirical work on 
LGBT topics by graduate students, and to broaden the recognition of this work within political science.

Award Committee: Andrew Reynolds, Chair, University of North Carolina, Chapel Hill; Douglas Page, Gettysburg College; Kelly Kollman, University of Glasgow.

\section{Recipient: Facundo E. Salles Kobilanski, Vanderbilt University}

Citation: By unanimous agreement, the committee for the 2019 Kenneth Sherrill Prize for the best dissertation proposal in the empirical study of LGBT Politics is delighted to award the prize to Facundo E. Salles Kobilanski for his proposal entitled "Out for Office, Out in Office: Public Opinion Towards Openly Lesbian, Gay and Bisexual Politicians in Brazil." Facundo's dissertation will use a sophisticated, mixed-method approach to examine how public opinion towards openly lesbian, gay and bisexual politicians in Latin America has developed over time and how such views shape these candidates' electability. Facundo begins by utilizing data from the AmericasBarometer to trace the change in public opinion towards LGB candidates in the region over time and explores the extent to which party affiliation as well as the religious identity of candidates mitigates negative attitudes towards such candidates. Facundo next turns his attention to LGB candidates in Brazil where rich electoral data from Brazil's state elections allow him to explore how and under what circumstance public opinion hinders the election of LGB candidates. He further uses an original survey experiment to test the effect that these candidates' religious affiliation has in mitigating negative attitudes towards LGB politicians. Finally, Facundo uses a qualitative case study of LGB incumbents in Brazil to explore how LGB stereotyping is applied to incumbent politicians. Through this rich research design Facundo's dissertation will help to move the focus of contemporary research on LGBT politics in Latin America from the substantive representation of policy outcomes to the descriptive representation of LGB politicians and the barriers they face towards gaining public office.

\section{LEO STRAUSS AWARD}

The Leo Strauss Award is given annually for the best dissertation in the field of political philosophy. The fund was developed by former students of Strauss' who sought to recognize his extraordinary influence on generations of students and his contributions to the

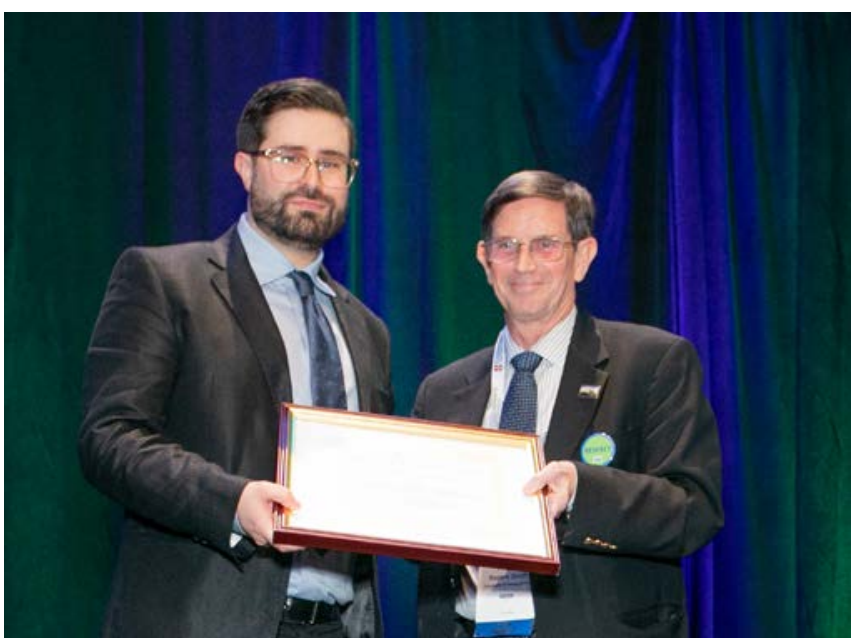

Facundo E. Salles Kobilanski (left) receives the Kenneth Sherrill Prize from APSA president Rogers Smith (right). field of political philosophy. He was a major figure in the department of political science at the University of Chicago, where he taught from 1949 to 1967.

Award Committee: Eileen Hunt Botting, Chair, University of Notre Dame; Jacob Levy, McGill University; Nancy Love, Appalachian State University.

\section{Recipient: Adam Lebovitz, Harvard University}

Citation: "Colossus: Constitutional Theory in America and France, 1776-1799" provides an in-depth historical analysis of the transatlantic travels of constitutional theories associated with the American, French, and other European revolutions. By illustrating how constitutional theories as well as Enlightenment ideals, political leaders, and philosophical texts, crisscrossed the Atlantic, it sheds new light on this formative period in the history of western democracies. "Colossus" has the potential to reinvigorate and transform the study of comparative constitutions. The analysis of the American and French revolutions here could also prompt reconsideration, for example, of how the Haitian and other colonial revolutions affected European constitutionalism. Its attention to Mary Wollstonecraft's conceptual contributions to these debates is also potentially transformative of a field that has historically left women out of the story of the emergence of modern constitutional political theory and practice from the intellectual and political tumult of the Revolutionary era.

The ambitious dissertation traces the influence of the early American state constitutions and of the debates about them through the years of the French Revolution, compellingly demonstrating how important the rival Pennsylvanian democratic and Massachusetts moderate models were in shaping institutional imaginations across the Atlantic. It then follows the intellectual path back again, as Americans followed the experience of constitutional experimentation in France and debated what lessons to learn from it. The dissertation is the kind of scholarship that would be called "magisterial" in a book by a senior scholar: broad in scope and deep in archival research, ambitious and confident in its scholarly voice.

It includes admirable attention to theoretical debate about institutional forms and rules, not only abstract questions of liberty or legitimacy. It restores rightful attention to the American state constitutional debates, and to Benjamin Franklin and (especially) John Adams as constitutional thinkers, attention that is typically eclipsed

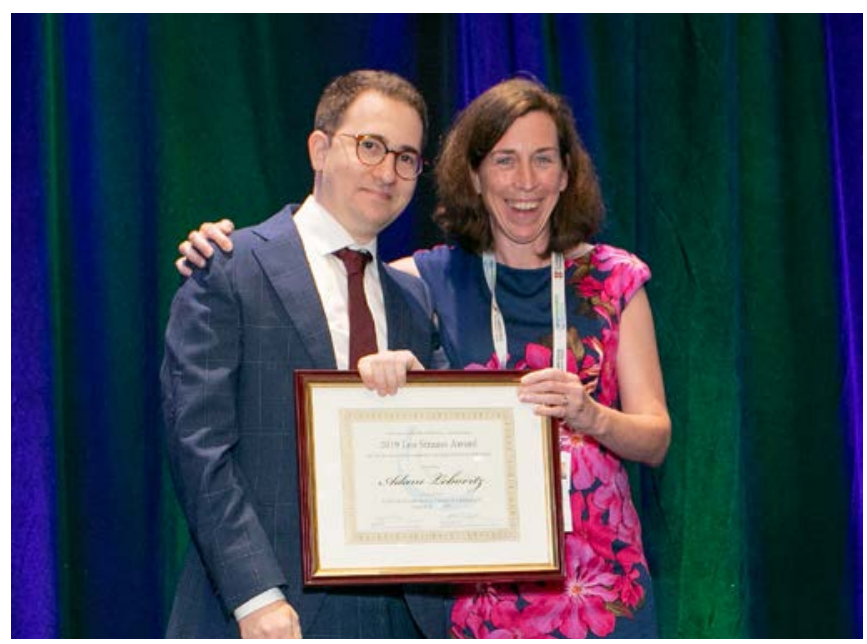

Adam Lebovitz (left) is presented with the Leo Strauss Award by award committee chair Eileen Hunt Botting (right). 


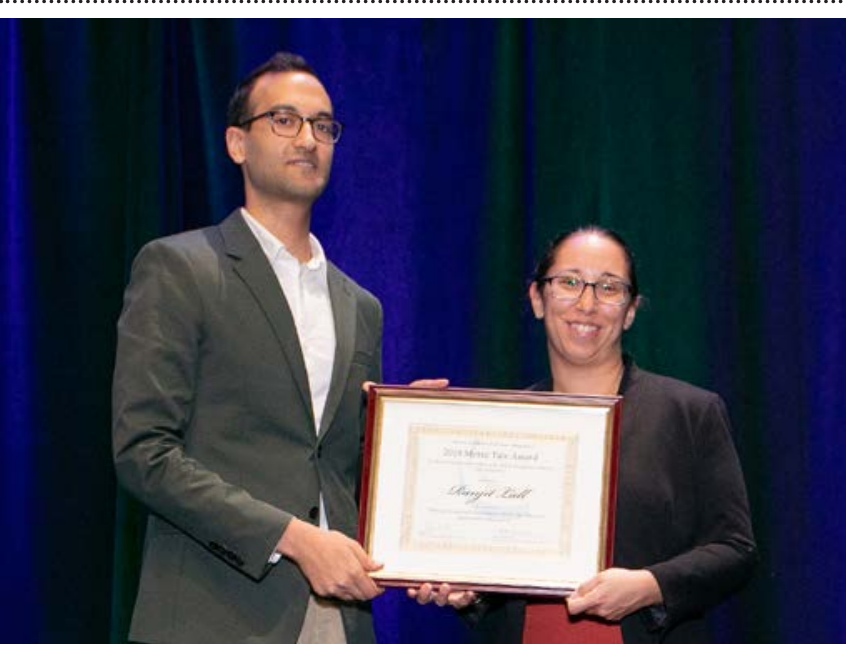

Ranjit Lall (left) receives the Merze Tate Award from award committee chair Tanisha Fazal (right)

by the 1787 constitution and the authors of the Federalist Papers. And, perhaps most importantly, it pushes the history of political thought toward the turn toward Atlantic history, and makes a compelling case for dislodging our understanding of both American and French revolutionary thought from the national silos in which they're so often kept.

\section{MERZE TATE AWARD}

The Merze Tate Award (formerly the Helen Dwight Reid Award) is given annually for the best dissertation successfully defended during the previous two years in the field of international relations, law, and politics.

Award Committee: Tanisha Fazal, Chair, University of Minnesota; Bridget Coggins, University of California, Santa Barbara; Seva Gunitsky, University of Toronto.

\section{Recipient: Ranjit Lall, Harvard University}

Citation:Ranjit Lall's dissertation, "Making International Organizations Work: The Politics of Institutional Performance" is an extremely impressive piece of scholarship that creatively links pressing questions in international relations with rigorous empirical testing. Lall's first question is: why are some international organizations (IOs) better performers than others? This question is extremely challenging in itself given inherent theoretical and measurement issues. Pushing back against a series of recent works that focus on the internal organizational dynamics of IOs, Lall finds that these organizations "work" when states want them to work. His quantitative analysis is based on an original dataset of IO performance derived from official state assessments as well as a remarkable survey of IO officials, and is supplemented by in-depth, interview-based case studies of the World Food Programme and Food and Agriculture Organization. He generates a novel way to answer whether an organization performs well by asking both the creators and inhabitants of IOs to assess their own performance. Lall then goes further, also asking: What are the consequences of variation in IO performance? His analysis of the effects of variation in IO performance pays specific attention to issues of accountability, speaking to the long-standing and important question of how democratic IOs are. He finds that the likelihood of accountability is driven in part by the type of IO; those that are focused on logistics, for example, are

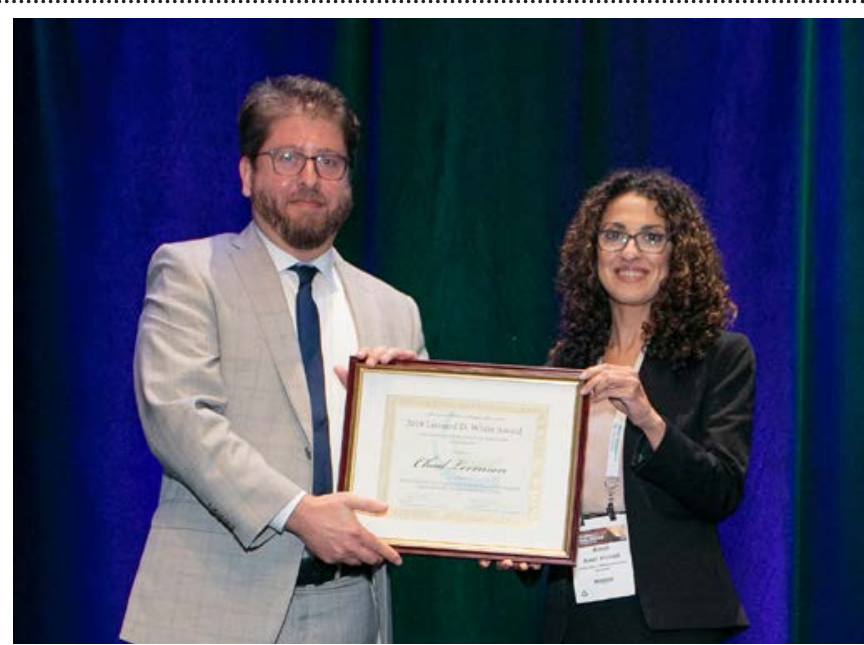

Chad Levinson (left) receives the Leonard D. White Award from program cochair Amel Ahmed (right).

less likely to be accountable than those whose role it is to provide financial resources. This dissertation is meticulously-researched, clearly-written, and innovatively theorized and analyzed. Lall has charted new avenues of research while bearing in mind crucial normative questions underlying global governance.

\section{LEONARD D. WHITE AWARD}

The Leonard D. White prize is awarded annually for the best dissertation successfully defended during the previous two years in the field of public administration.

Award Committee: Martin Lodge, Chair, London School of Economics; Dorothy Daley, University of Kansas; William G. Resh, University of Southern California.

\section{Recipient: Chad Levinson, University of Chicago}

Citation: Among a very strong set of exciting theses that highlighted the strength of the field, the committee selected Chad Levinson (University of Chicago) as this year's winner of APSA's White prize. The committee was particularly drawn to this dissertation given its interesting development of the 'moral subsidy' argument which was established in theoretically interesting terms. The thesis also displayed varied methodological approaches and exciting empirical work. Taken together, the thesis offered important new insights and a fresh perspective for the field of public administration, especially also in terms of appealing to an international readership.

\section{Paper and Article Awards}

\section{FRANKLIN L. BURDETTE/PI SIGMA ALPHA AWARD}

The Franklin L. Burdette/Pi Sigma Alpha Award is given annually for the best paper presented at the previous year's annual meeting. The award is supported by Pi Sigma Alpha.

Award Committee: Adria Lawrence, Chair, Johns Hopkins University; William Bianco, Indiana University; Paul Frymer, Princeton University.

Recipients: Nikhar Gaikwad, Columbia University; Pavithra Suryanarayan, Johns Hopkins University 
Citation: The committee is pleased to award the 2019 Franklin L. Burdette Pi Sigma Alpha Award to Nikhar Gaikwad and Pavithra Suryanarayan for their paper: "Economic and Ethnic Determinants of Trade Preferences: Evidence from India." This empirically-rich paper makes two provocative and important arguments. First, using multiple large surveys of Indian voters, the paper shows that although trade-liberalization is often understood to be elite-driven and harmful to lower-skilled workers, those workers may actually favor trade liberalization when their domestic environment discriminates against them. Trade liberalization can provide new opportunities for economic advancement for members of ethnic groups who have historically experienced discrimination. The second contribution lies in the paper's assessment of whether individuals express solidarity with their co-ethnics when they consider who benefits and who loses from trade liberalization. Drawing on an carefully-conducted original survey experiment, the paper provides evidence that individuals from privileged ethnic groups lack solidarity with their co-ethnics, focusing exclusively on self-interested calculations. In contrast, ethnicity shaped the trade preferences of individuals from discriminated groups. This is a striking finding, since we might expect both the privileged and the underprivileged to prioritize ethnic identity, either to uphold the status quo or to upend it. The arguments of the paper are carefully developed and they have implications not only for politics in the world's largest democracy, but also beyond the Indian context. Scholars interested in labor markets, ethnicity, and trade liberalization will find much to admire in this powerfully argued piece of new scholarship.

\section{HEINZ EULAU AWARD: AMERICAN POLITICAL SCIENCE} REVIEW

The Heinz Eulau Award is given annually for the best article published in the American Political Science Review in the past calendar year. The award is supported by Cambridge University Press.

Award Committee:Elizabeth Zechmeister, Chair,Vanderbilt University; Wendy Tam Cho, University of Illinois, Urbana-Champaign; Scott Gates, PRIO and University of Oslo.

Recipients: Adam Michael Auerbach, American University; Tariq Thachil, Vanderbilt University

Citation: Auerbach and Thachil's article "How Clients Select Brokers: Competition and Choice in India's Slums" examines the role

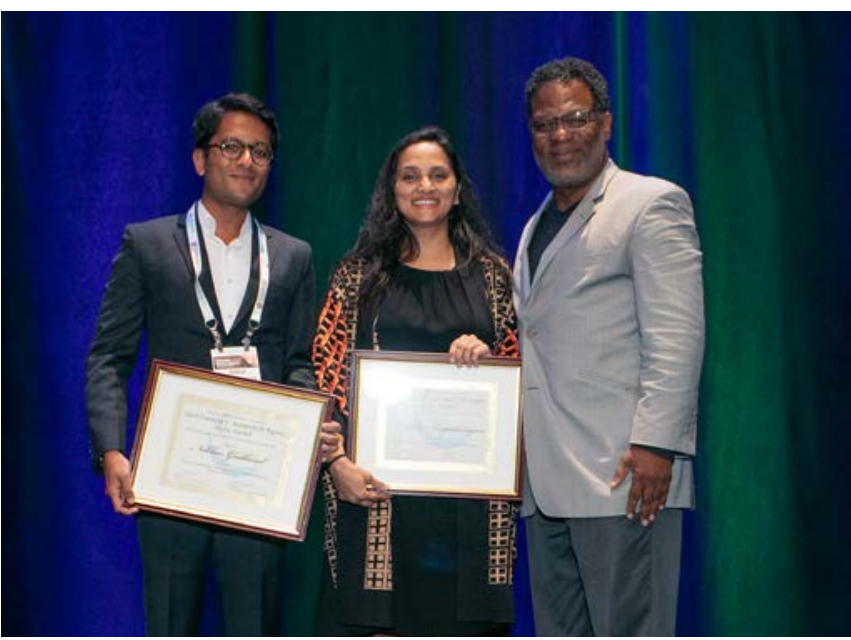

Nikhar Gaikwad (left) and Pavithra Suryanarayan (center) receive the Franklin L. Burdette/Pi Sigma Alpha Award from program cochair Christopher Sebastian Parker of clients in shaping local brokerage environments. Their article is informed by an examination of client preferences for slum leaders in urban India. In contrast to most work on clientelism where the political broker serves as the central player, Auerbach and Thachil demonstrate that competition between brokers confers clients with considerable agency to select local leaders. They use the case of India, an iconic developing democracy, to inform their broader theoretical framework in the study of distributive, ethnic, and urban politics.

The authors drew upon years of fieldwork in India in their survey research design. They employed a forced-choice conjoint survey experiment where respondents are presented with information on the randomized attributes of two slum leaders and then asked which they prefer. This design enabled them to disentangle the effects of observationally correlated attributes. It also reduces social desirability concerns by providing a form of confidentiality in response justifications.

The committee was especially impressed with the care that was exemplified in varied and numerous aspects of the project. Deep domain knowledge informed the methods, and both were thoughtful and thorough. The project was unique and did not seek to provide an incremental addition to existing work, but rather forged its own path in creating new theory, unique data, innovative design, and forceful analysis.

\section{HEINZ EULAU AWARD: PERSPECTIVES ON POLITICS}

The Heinz Eulau Award is given annually for the best article published in Perspectives on Politics in the past calendar year. The award is supported by Cambridge University Press.

Award Committee: Elizabeth Zechmeister, Chair,Vanderbilt; Nuno Monteiro, Yale University; Natasha Borges Sugiyama, University of Wisconsin, Madison.

\section{Recipients: Mark E. Button, University of Utah}

Citation: In "Bounded Rationality without Bounded Democracy: Nudges, Democratic Citizenship, and Pathways for Building Civic Capacity" (December 2018), Mark E. Button paints a bleak picture of the consequences of "the nudging state" for democratic life. Building on recent scholarship in psychology and behavioral economics, the "nudging" approach has become a powerful force in shaping public policy across the world. Advocates of the "nudging

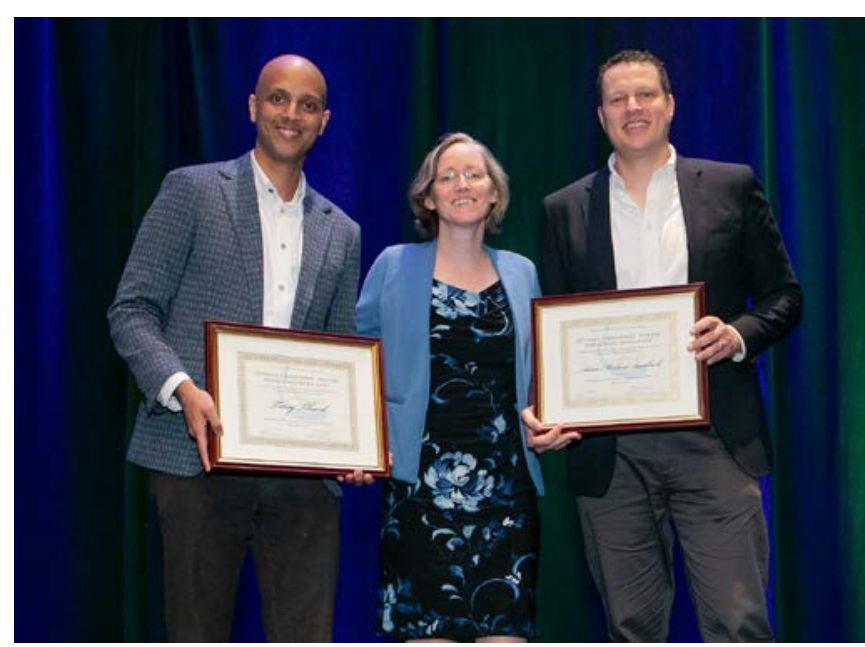

Adam Michael Auerbach (right) and Tariq Thachil (left) receive the Heinz Eulau Award for the best article published in the American Political Science Review from award committee chair Elizabeth Zechmeister. 
state" argue that policy "nudges" can shape choice architectures in ways that lead citizens to advance desirable policy goals while preserving their freedom of choice. In his vigorous critique, Button makes clear the deeper problems this approach presents for long-term democratic reasoning. By harnessing shortcomings to reasoning, the nudging approach to public policy undermines democratic life. It allows the state to pursue its policy objectives through "opaque behavioral interventions that do not meaningfully include, engage, or empower citizens in their own self-governance." In effect, Button argues, nudging undermines personal and institutional qualities essential to democratic life, such as the "democratic-deliberative capacities and virtues of public reasoning, reciprocal listening, and pursuing mutually workable agreements to collective problems." This scholarly tour de force distills vast literatures in political theory and public policy in support of a powerful case that will have a lasting impact on a broad swath of important scholarly, political, and policy issues. 